\title{
Analysis of Ganglion Cell Complex and Retinal Nerve Fiber Layer Thicknesses in Turkish Population
}

\section{Türk Halkında Ganglion Hücre Kompleksinin ve Retina Sinir Lifi Kalınıı̆ının Değerlendirilmesi}

Mehmet Adam ${ }^{1}$,

Seray Aslan Bayhan²,

Hasan Ali Bayhan²,

Ersin Muhafiz ${ }^{3}$,

Sukran Bekdemir

Canan Gurdal ${ }^{5}$

${ }^{1}$ Aksaray University, Faculty of Medicine Department of Ophthalmology, Aksaray,

Turkey

${ }^{2}$ Bozok University Faculty of Medicine

Department of Ophthalmology, Yozgat,

Turkey

${ }^{3}$ Kafkas University, Faculty of Medicine

Department of Ophthalmology, Kars, Turkey

${ }^{4}$ Polatli Duatepe State Hospital Department

of Ophthalmology, Ankara, Turkey

${ }^{5}$ Dünyagöz Hospital Department of

Ophthalmology, Ankara, Turkey

Gelis Tarihi/Received: 18 August 2020

Kabul Tarihi/Accepted: 1 October 2020

Address correspondence to: Mehmet Adam, Aksaray University, Faculty of Medicine Department of Ophthalmology, Aksaray, Turkey

e-mail: drmehmetadam@gmail.com

\section{ORCID}

Mehmet Adam

https://orcid.org/0000-0003-0552-5212

Seray Aslan Bayhan

https://orcid.org//0000-0001-8514-9450 Hasan Ali Bayhan

https://orcid.org/0000-0002-3364-6890

\section{Öz}

Amaç: Sağlıklı bireylerde yaş ve cinsiyetin ganglion hücre kompleksi ve retina sinir lifi kalınlığı üzerine etkisinin değerlendirilmesi amaçlandı.

Hastalar ve Yöntem: Bu kesitsel çalışmada Kasım 2012 - Mayıs 2013 tarihleri arasında yaşları 10-84 arasında değişen 393 sağlıklı katılımcıyı değerlendirdik. Yaşa bağlı değişikler lineer regresyon analizi ve Pearson korelasyon analizi ile incelendi. Retina sinir lifi kalınlığı ve ganglion hücre kompleksi arasındaki ilişki pearson korelasyon testi ile değerlendirildi.

Bulgular: Tüm populasyonun ortalama retina sinir lifi kalınlığı 108.94 $\pm 9.77 \mu \mathrm{m}$ idi ve yıllık 0.101 $\mu \mathrm{m}$ azalmaktaydı. En önemli azalma üst temporal bölümde görüldü. Üst kadran hariç retina sinir lifi kalınlığında cinsiyete göre fark bulunamadı. Ortalama ganglion hücre kompleksi kalınlığı $97.45 \pm 6.42 \mu \mathrm{m}$ olarak bulundu ve her yıl $0.043 \mu \mathrm{m}$ azalmaktaydı. Cinsiyetle ganglion hücre kalınlığı arasında bir ilişki bulunmazken retina sinir lifi ile ganglion hücre kompleksi arasında anlamlı korelasyon tespit edilmiştir.

Sonuç: Retina sinir lifi kalınlığı ve ganglion hücre kompleksi kalınlığı yaşla birlikte önemli ölçüde azalmaktadır ancak ganglion hücre kalınlığı daha az etkilenmektedir.

Anahtar Kelimeler: Optik kohorens tomografi, retina sinir lifi kalınlığı, ganglion hücre kompleksi, Türk halkı

\section{Abstract}

Aim: To determine the effects of age and sex on retinal ganglion cell complex thickness and retinal nerve fiber layer thickness in the eyes of healthy individuals.

Patients and Methods: We evaluated 393 healthy subjects aged 10-84 years in a cross-sectional study between November 2012 and May 2013. Linear regression analysis and Pearson's correlation were performed to analyze the difference in the age-related changes. We evaluated the relationship between the retinal nerve fiber layer thickness and ganglion cell complex thickness using Pearson's correlation. Results: The whole population mean retinal nerve fiber layer thickness was $108.94 \pm 9.77 \mu \mathrm{m}$, and decreased by $0.101 \mu \mathrm{m} /$ year. The most significant decrease was in the supero-temporal sector. There was no difference in the retinal nerve fiber layer thickness between sexes, except for the superior quadrant. The mean ganglion cell complex thickness was $97.45 \pm 6.42 \mu \mathrm{m}$, and decreased by $0.043 \mu \mathrm{m} /$ year. There was no relationship between sex and ganglion cell complex thickness. The mean retinal nerve fiber layer and ganglion cell complex thicknesses exhibited a significant correlation.

Conclusion: The ganglion cell complex thickness and retinal nerve fiber layer thickness decreased significantly with age but ganglion cell complex thickness was less affected.

Key words: Optical coherence tomography, retinal nerve fiber layer, ganglion cell complex, Turkish population

Ersin Muhafiz

https://orcid.org/0000-0002-8281-8767

Sukran Bekdemir

https://orcid.org/0000-0003-1925-9584

Canan Gurdal

https://orcid.org/0000-0003-3017-3853

Cite this article as: Adam M, Bayhan SA, Bayhan HA, Muhafiz E, Bekdemir S, Gurdal C. Analysis of Ganglion Cell Complex and Retinal Nerve Fiber Layer Thicknesses in Turkish Population. Selcuk Med J 2021;37(1): 17-23

Disclosure: None of the authors has a financial interest in any of the products, devices, or drugs mentioned in this article. The research was not sponsored by an outside organization. All authors have agreed to allow full access to the primary data and to allow the journal to review the data if requested. 


\section{INTRODUCTION}

Glaucoma is an optic neuropathy characterized by the progressive loss of retinal ganglion cells (RGCs) and their respective axons (1). The human retina contains $>1$ million RGCs, and $\sim 50 \%$ are located within $4.5 \mathrm{~mm}$ of the center of the fovea (2). Because the macular region contains a significant portion of the RGCs, an evaluation of ganglion cell changes may assist in the diagnosis of glaucoma (3$6)$. In recent years, the evaluation of the ganglion cell complex thickness (GCCT) and retinal nerve fiber layer thickness (RNFLT) has become important in the diagnosis and follow up of glaucoma patients (4,7-10). The ganglion cell complex (GCC) comprises three tissue layers: the retinal nerve fiber layer (RNFL), RGCs, and the inner-plexiform layer. RNFL and GCC thicknesses may vary according to factors such as race, age, axial length, and refraction (11-14).

There is no commercially available optical coherence tomography (OCT) device with a database for the Turkish population. To our knowledge, although studies of the RNFL in healthy Turkish populations using various OCT devices have been performed, no such data on the GCC are available in healthy adult Turkish population (15-19). Therefore, we aimed to evaluate RNFL and GCC thicknesses in Turkish subjects according to age and sex.

\section{PATIENTS AND METHODS}

This study followed the tenets of the Declaration of Helsinki. Informed consent was obtained from the healthyparticipantsaftertheywereprovidedinformation about the nature and possible consequences of the study. The study protocol was approved by Bozok University Faculty of Medicine, Non-interventional Clinical Trial (Decision No:2013,6/10). The current study was performed at the Ophthalmology Clinic of Bozok University Medical Faculty between November 2012 and May 2013. A total of 393 (212 female and 181 male) healthy individuals were enrolled. The subjects were healthy individuals employed in the hospital or were associates of the patients. The best-corrected visual acuity was determined using the Snellen chart. After slit-lamp and fundus examination using a 90-D lens, the same physician determined the intraocular pressure (IOP) by Goldmann applanation tonometry. Then, the peripapillary RNFL and GCC thicknesses were determined using the RTVue-100 SD-OCT device (Optovue Inc., Fremont, CA, USA). Measurements were taken in triplicate for each eye and B-scan image segmentations were inspected on the screen. The best provided signal strength higher than 60 was used for analysis. Subjects who had undergone intraocular surgery, an IOP $>21$ $\mathrm{mmHg}$, diabetic retinopathy, a refractive error $> \pm 2 \mathrm{D}$, a corrected visual acuity worse than $20 / 20$, a history of glaucoma, ocular trauma, or a history of uveitis, were excluded. Moreover, patients who had any sign of peripapillary choroidal atrophy and an abnormal ophthalmoscopic examination of the optic nerve head, macula, and retinal vasculature were excluded.

Participants were classified according to decade between the ages of 10 and 69 years. Subjects $>70$ years were evaluated as a single group. The measurements were performed without pupil dilation by the same researcher.

\section{OCT Measurements}

Measurements were performed using the RTVue-100 SD OCT instrument with software version 6.1. The working principle of the device is described in detail elsewhere (20). The following parameters were evaluated: the mean RNFLT around the optic nerve head; the four-quadrants RNFLT (inferior, nasal, superior, and temporal); all eight RNFLT sectors (TU: temporal-upper; ST: supero-temporal; IT: inferotemporal; TL: temporal lower; SN: supero-nasal; NU: nasal-upper; NL: nasal lower; and IN: infero-nasal); and the mean GCC, IGCC, and SGCC thicknesses.

\section{Statistical Analysis}

We used the Statistical Package for the Social Sciences (SPSS) software (Worldwide Headquarters SPSS Inc. 18.0 Windows package program) for statistical analysis. Descriptive findings are given as the means \pm standard deviation. The normality of the data distribution was assessed using the KolmogorovSmirnov test. Comparisons between groups were performed using Student's t-test; one-way analysis of variance was used for multiple comparisons between groups. Pearson's correlation test was performed for correlation analysis.Linear regression analysis was performed to determine the mean decrease in the RNFLT and GCC thickness according to age. Annual rates of change in the RNFLT and GCC thickness are shown as percentages/year. $A$ value of $p<0.05$ was considered to indicate statistical significance.

\section{RESULTS}

The right eyes of 393 subjects were analyzed according to sex and age. There were 212 (53.95\%) females and $181(46.05 \%)$ males. The mean age was $39.90 \pm 17.57$ (range, 10-84) years. The distributions of the subjects according to age group 
Table 1. Distribution of subjects according to age groups and gender

\begin{tabular}{|c|c|c|c|c|c|c|c|}
\hline Age groups & $10-19$ & $20-29$ & $30-39$ & $40-49$ & $50-59$ & $60-69$ & $\geq 70$ \\
\hline Female & 40 & 28 & 34 & 48 & 34 & 19 & 9 \\
\hline Male & 26 & 26 & 33 & 34 & 37 & 16 & 9 \\
\hline Total & 66 & 54 & 67 & 82 & 71 & 35 & 18 \\
\hline
\end{tabular}

Table 2. Retinal nerve fiber layer thickness measurements (mean $\pm S D$ in micrometers) according to gender

\begin{tabular}{llllll}
\hline & Average & Superior & Temporal & Inferior & Nasal \\
Female $(n=212)$ & $109.79 \pm 9.72$ & $134.69 \pm 15.16$ & $83.97 \pm 10.98$ & $142.29 \pm 18.32$ & $78.00 \pm 11.49$ \\
Male $(n=181)$ & $107.95 \pm 9.78$ & $130,65 \pm 15.17$ & $85.11 \pm 11.16$ & $139.52 \pm 16.57$ & $76.41 \pm 11.42$ \\
$\mathrm{p}$ & 0.06 & 0.01 & 0.31 & 0.12 & 0.17 \\
\hline
\end{tabular}

and gender are given in Table 1. The mean RNFLT was $108.94 \pm 9.77$ (range, $77-140$ ) $\mu \mathrm{m}$. Although the mean RNFLT was greater in females than in males, the difference was not significant $(109.80 \pm 9.71$ and 107.94 $\pm 9.72 \mu \mathrm{m}$, respectively, $p=0.06)$. The RNFLTs of the superior, temporal, inferior, and nasal quadrants were $132.8 \pm 15.8,84.5 \pm 11.1,140.7 \pm 18.1$, and $77.5 \pm 11.7 \mu \mathrm{m}$, respectively, independent of sex. The superior RNFLT was significantly greater in females than in males $(134.69 \pm 15.16$ and $130.65 \pm 15.17 \mu \mathrm{m}$, respectively, $p=0.01$ ). Table 2 shows the mean and four-quadrants RNFLTs of both sexes. The mean RNFLT exhibited a significant inverse correlation with age $(p<0.001, r=-0.17)$, while the greatest correlation was for the superior RNFLT $(p<0.001, r=-0.18)$. The decrease in the mean RNFLT was $0.101 \mu \mathrm{m} /$ year $(95 \%$ confidence interval $(\mathrm{Cl}),-0.151,-0.051$; linear regression analysis, $p=0.001)$, with the most significant decrease being in the ST sector $(0.197$ $\mu \mathrm{m} /$ year, $95 \% \mathrm{Cl},-0.293,-0.101$; linear regression analysis, $p<0.001)$. Detailed data on the mean, four quadrants, eight sectors and linear regression of the RNFLT according to age group are presented in Table 3.

The mean GCC, SGCC, and IGCC thicknesses of all population were $97.45 \pm 6.42,97.3 \pm 6.7$, and $97.9 \pm 6.7 \mu \mathrm{m}$, respectively. The male and female mean GCC thicknesses were $97.70 \pm 6.53$ and $97.24 \pm 6.34$ $\mu \mathrm{m}$, respectively $(p=0.48)$. The decrease in the mean GCC was $0.043 \mu \mathrm{m} /$ year $(95 \% \mathrm{Cl},-0.079,-0.007$; linear regression analysis, $p=0.019)$, while the most significant decrease was in the SGCC thickness $(0.053$ $\mu \mathrm{m} /$ year, $95 \% \mathrm{Cl},-0.092,-0.015$; linear regression analysis, $p=0.007)$. Detailed information according to age group is presented in Table 4 . The mean GCC thickness exhibited a significant inverse correlation

Table 3. Retinal nerve fiber layer thickness measurements (mean $\pm S D$ in micrometers) and linear regression analysis according to age groups.

\begin{tabular}{|c|c|c|c|c|c|c|c|c|c|c|c|c|}
\hline & $\begin{array}{l}\text { Overall } \\
(n=393)\end{array}$ & $\begin{array}{l}10-19 y \\
(n=67)\end{array}$ & $\begin{array}{l}20-29 y \\
(n=54)\end{array}$ & $\begin{array}{l}30-39 y \\
(n=67)\end{array}$ & $\begin{array}{l}40-49 y \\
(n=82)\end{array}$ & $\begin{array}{l}50-59 y \\
(n=71)\end{array}$ & $\begin{array}{l}60-69 y \\
(n=35)\end{array}$ & $\begin{array}{l}70 \text { and over } \\
(n=18)\end{array}$ & p1 & $\begin{array}{l}\text { Slope } \\
\mu \mathrm{m} / \mathrm{y}\end{array}$ & $\% 95 \mathrm{Cl}$ & p2 \\
\hline $\begin{array}{l}\text { Mean } \operatorname{RNFLT}(\mu \mathrm{m}) \\
\text { Quadrants }(\mu \mathrm{m})\end{array}$ & $108,9 \pm 9,8$ & $111,3 \pm 8,7^{\mathrm{a}}$ & $109,3 \pm 9,0^{\text {ab }}$ & $109,1 \pm 10,1^{\text {ab }}$ & $109,4 \pm 9,0^{\text {ab }}$ & $110,1 \pm 9,7^{\text {ab }}$ & $104,6 \pm 10,0^{b c}$ & $100,3 \pm 12,5^{c}$ & $<0.001$ & -0.101 & $-0,151,-0,051$ & 0,001 \\
\hline Superior & $132,8 \pm 15,8$ & $137,4 \pm 14,0^{\mathrm{a}}$ & $134,0 \pm 15,1^{\mathrm{a}}$ & $132,4 \pm 15,8^{\mathrm{a}}$ & $132,2 \pm 16,1^{\mathrm{a}}$ & $133,6 \pm 15,8^{\mathrm{a}}$ & $129,9 \pm 16,2^{\mathrm{ab}}$ & $117,4 \pm 13,5 b^{c}$ & $<0.001$ & $-0,153$ & $-0,298,-0,067$ & $<0,001$ \\
\hline Temporal & $84,5 \pm 11,1$ & $84,4 \pm 9,6^{a}$ & $85,7 \pm 9,3^{\mathrm{a}}$ & $86,9 \pm 13,6^{\mathrm{a}}$ & $85,2 \pm 10,6^{a}$ & $84,3 \pm 10,6^{\mathrm{a}}$ & $80,8 \pm 10,1^{\mathrm{a}}$ & $78,8 \pm 14,4^{\mathrm{a}}$ & 0.061 & -0.080 & $-0,142,-0,018$ & 0,012 \\
\hline Inferior & $140,7 \pm 18,1$ & $144,4 \pm 16,7^{\mathrm{a}}$ & $140,8 \pm 18,7^{\mathrm{a}}$ & $139,4 \pm 18,1^{\text {a }}$ & $140,8 \pm 18,7^{\mathrm{a}}$ & $143,1 \pm 17,3^{\mathrm{a}}$ & $133,8 \pm 16,5^{\mathrm{a}}$ & $136,0 \pm 23,2^{\mathrm{a}}$ & 0.076 & $-0,078$ & $-0,177,0.021$ & 0.122 \\
\hline $\begin{array}{l}\text { Nasal } \\
\text { RNFLT } \operatorname{sectors}(\mu \mathrm{m})\end{array}$ & $77,5 \pm 11,7$ & $79,5 \pm 11,7 a$ & $77,6 \pm 11,2^{\mathrm{ab}}$ & $76,5 \pm 11,7^{\mathrm{ab}}$ & $78,4 \pm 12,9^{\mathrm{ab}}$ & $79,1 \pm 10,9^{a}$ & $73,3 \pm 10,7^{\mathrm{ab}}$ & $69,28 \pm 10,7^{b}$ & 0.007 & $-0,072$ & $-0,137,-0,008$ & 0.028 \\
\hline ST & $145.7 \pm 17.3$ & $150.5 \pm 15.8^{\mathrm{a}}$ & $148.9 \pm 19,3^{\mathrm{ab}}$ & $145.3 \pm 16.2^{\mathrm{a}}$ & $145.9 \pm 18.2^{\mathrm{ab}}$ & $145.9 \pm 18.2^{\mathrm{ab}}$ & $137.9 \pm 16.4^{\mathrm{bc}}$ & $131.3 \pm 13.1^{\circ}$ & 0.001 & -0.197 & $-0,293,-0.101$ & $<0.001$ \\
\hline SN & $120.0 \pm 18.5$ & $124.1 \pm 18.0^{\mathrm{a}}$ & $121.7 \pm 17.6^{\mathrm{a}}$ & $117.1 \pm 16.4^{\mathrm{ab}}$ & $120.4 \pm 18.4^{\mathrm{a}}$ & $121.6 \pm 18.6^{\mathrm{a}}$ & $120.0 \pm 21.8^{\mathrm{a}}$ & $102.8 \pm 16.0^{\mathrm{b}}$ & 0.002 & $-0,127$ & $-0.231,-0.022$ & 0.018 \\
\hline NU & $82.3 \pm 13.0$ & $84.8 \pm 13.6^{a}$ & $83,2 \pm 12.1^{\mathrm{ab}}$ & $83.9 \pm 17.6^{\mathrm{ab}}$ & $82.2 \pm 13,1^{\mathrm{ab}}$ & $84.2 \pm 11.9^{\mathrm{ab}}$ & $77.1 \pm 11.7^{\mathrm{ab}}$ & $73.7 \pm 13.3^{\mathrm{b}}$ & 0.014 & -0.112 & $-0.189,-0.034$ & 0.005 \\
\hline NL & $72,3 \pm 11.3$ & $74.4 \pm 11.8^{\mathrm{a}}$ & $72.1 \pm 11.3^{\mathrm{a}}$ & $71.2 \pm 10.8^{\mathrm{a}}$ & $72.6 \pm 10.9^{a}$ & $74.1 \pm 11,4^{\mathrm{a}}$ & $69.0 \pm 11.7^{\mathrm{a}}$ & $67.1 \pm 9.5$ & 0.075 & -0.040 & $-0.104,0.024$ & 0.220 \\
\hline IN & $128.1 \pm 23.7$ & $131,5 \pm 23.7^{\mathrm{a}}$ & $126.9 \pm 25.8^{\mathrm{a}}$ & $126.4 \pm 23.5^{\mathrm{a}}$ & $129.6 \pm 23.1^{\mathrm{ab}}$ & $129.4 \pm 24.3^{\mathrm{a}}$ & $122.2 \pm 22.1^{\mathrm{a}}$ & $124.5 \pm 22.4^{\mathrm{a}}$ & 0.559 & -0.044 & $-0.179,0.091$ & 0.518 \\
\hline IT & $154,6 \pm 18.8$ & $156.6 \pm 16.9^{\mathrm{a}}$ & $155.5 \pm 17.2^{\mathrm{ab}}$ & $155.7 \pm 20.9^{\mathrm{a}}$ & $155.2 \pm 17,9^{\mathrm{ab}}$ & $156.7 \pm 18.9^{\mathrm{a}}$ & $144.1 \pm 17.8^{\mathrm{b}}$ & $148.5 \pm 22,5^{\mathrm{ab}}$ & 0.020 & -0.121 & $-0.227,-0,015$ & 0.026 \\
\hline TL & $81,3 \pm 12,1$ & $81.2 \pm 10.0^{\mathrm{a}}$ & $83.7 \pm 11.4^{\mathrm{a}}$ & $83.0 \pm 14.0^{\mathrm{a}}$ & $80.9 \pm 11.9^{\mathrm{a}}$ & $80.0 \pm 11.1^{\mathrm{a}}$ & $79.0 \pm 13.1^{\mathrm{a}}$ & $77.7 \pm 17.7^{\mathrm{a}}$ & 0.303 & -0.077 & $-0.145,-0.008$ & 0.028 \\
\hline TU & $87,7 \pm 13.2$ & $87.0 \pm 12.4^{a}$ & $87.4 \pm 11.3^{\mathrm{a}}$ & $89.7 \pm 15.7^{\mathrm{a}}$ & $88.8 \pm 12.3^{\mathrm{a}}$ & $89.2 \pm 14.0^{\mathrm{a}}$ & $82.8 \pm 14.9^{\mathrm{a}}$ & $81.7 \pm 14.9^{a}$ & 0.068 & -0.052 & $-0.127,-0.022$ & 0.169 \\
\hline
\end{tabular}

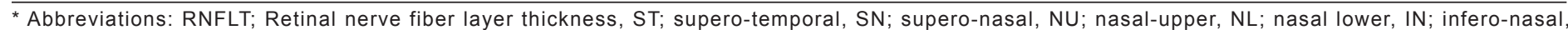
IT; infero-temporal, TL; temporal lower TU; Temporal-upper,

Different subscripts in a row indicate statistically significance difference.

p1 shows that intergroup difference significance with ANOVA

p2 shows that significance of linear regression analysis 
Table 4. Ganglion cell complex thickness measurements (mean \pm SD in micrometers) and linear regression analysis according to age groups.

\begin{tabular}{|c|c|c|c|c|c|c|c|c|c|c|c|c|}
\hline & $\begin{array}{c}\text { Total } \\
(n=393)\end{array}$ & $\begin{array}{c}10-19 \text { age } \\
(n=67)\end{array}$ & $\begin{array}{c}20-29 \text { age } \\
(n=54)\end{array}$ & $\begin{array}{c}30-39 \text { age } \\
(n=67)\end{array}$ & $\begin{array}{c}40-49 \text { age } \\
(n=82)\end{array}$ & $\begin{array}{c}50-59 \text { age } \\
(n=71)\end{array}$ & $\begin{array}{c}60-69 \text { age } \\
(n=35)\end{array}$ & $\begin{array}{c}70 \text { and ove } \\
(n=18)\end{array}$ & & P1 & $\begin{array}{l}\text { Slope } \\
\mu \mathrm{m} / \mathrm{y}\end{array}$ & P2 \\
\hline GCC & $97.5 \pm 6.4$ & $97.9 \pm 5.3^{\mathrm{a}}$ & $97.1 \pm 5.5^{\mathrm{ab}}$ & $98.4 \pm 6.5^{\mathrm{a}}$ & $98.3 \pm 6.4^{\mathrm{a}}$ & $98.4 \pm 6.6^{\mathrm{a}}$ & $94.0 \pm 7.3^{b}$ & $92.6 \pm 6.4^{b}$ & $<0.001$ & -0.043 & $-0.079,-0.007$ & 0.019 \\
\hline IGCC & $97.9 \pm 6.6$ & $98.2 \pm 5.4^{\mathrm{a}}$ & $97.5 \pm 5.3^{\mathrm{ab}}$ & $98.7 \pm 6.1^{\mathrm{a}}$ & $98.8 \pm 6.6^{\mathrm{a}}$ & $98.7 \pm 7.1^{\mathrm{a}}$ & $93.8 \pm 8.1^{\mathrm{b}}$ & $93.2 \pm 6.8^{\mathrm{b}}$ & $<0.001$ & -0.046 & $-0.083,-0.008$ & 0.017 \\
\hline SGCC & $97.3 \pm 6.7^{\mathrm{a}}$ & $98.7 \pm 6.1^{\mathrm{a}}$ & $99.4 \pm 6.3^{\mathrm{a}}$ & $97.6 \pm 7.6^{\mathrm{a}}$ & $96.9 \pm 6.9^{a}$ & $96.3 \pm 6.6^{a}$ & $96.7 \pm 7.7^{\mathrm{a}}$ & $96.1 \pm 7.0^{\mathrm{a}}$ & 0.135 & -0.053 & $-0.092,-0.015$ & 0.007 \\
\hline
\end{tabular}

* Abbreviations: GCC Ganglion cell complex, IGCC Inferior ganglion cell complex ,SGCC Superior ganglion cell complex

Different subscripts in a row indicate statistically significance difference

p1 shows that intergroup difference significance with ANOVA

p2 shows that significance of linear regression analysis

with age $(p=0.02, r=-0.12)$, with the greatest correlation for the SGCC thickness $(p=0.01, r=-0.14)$. The mean GCC thickness and RNFLT exhibited a significant correlation $(p<0.001, r=0.630)$. Although the IGCC thickness was significantly correlated with the inferior RNFLT, no correlation was found between the SGCC thickness and the superior RNFLT $(p<0.001, r=0.494$ and $p=0.106, r=0.082$, respectively).

\section{DISCUSSION}

We investigated the variation in GCC thickness and RNFLT measurements obtained by RTVue OCT in healthy subjects according to sex and defined age group, and the correlation between the GCC thickness and RNFLT. Although several studies have investigated the relationship between age and the RNFLT using other OCT devices, we found no data on the relationship between the GCC and age in the healthy Turkish population (15-17). In this study, we demonstrated that the RNFLT and GCC thickness are inversely correlated with age. A strong correlation was also found between the RNFLT and GCC thickness in healthy individuals.

Currently, two in vivo methods of determine the RNFLT are available scanning laser polarimetry and OCT. OCT technology has changed considerably in recent years with the incorporation of spectral-domain (SD) imaging, which offers important advantages over traditional time-domain (TD)-OCT techniques (21). The TD-OCT and SD-OCT determined RNFLT measurements are dissimilar, and RNFLT values differ between individual SD-OCT devices, and are thus not interchangeable (22). Therefore, studies of the variation in the RNFLT in a normal population using SD-OCT are required. To our knowledge, this is the first study to evaluate RNFLT and GCC thickness in healthy Turkish individuals using RTVue. We also investigated, for the first time, the correlation between these two parameters in healthy Turkish subjects.

Relationships among the RNFLT, Age and Sex
The overall mean RNFLT was 108.94 \pm 9.77 $\mu \mathrm{m}$. Although this RNFLT is slightly greater than in previous studies of the Stratus, Spectralis, and Cirrus devices, it is compatible with an earlier study using an RTvue OCT device $(13,15,16,23,24)$. In a study that compared three OCT devices for healthy and glaucomatous eyes, and found that the mean and four quadrant values obtained using the RTvue were greater than those using Stratus, Spectralis, and Cirrus OCT in both groups (23). In agreement with previous reports, we found that the mean inferior quadrant had the greatest thickness, followed by the superior, temporal and nasal quadrant. Previous studies reported that $56-79 \%$ of normal eyes comply with the thickest inferiorly and thinnest temporally (ISNT) rule (25-26). There are also articles that do not obey this rule and support our finding. The Singapore Chinese Eye Study (27) reported a descending RNFLT in the order inferior, superior, temporal, and nasal sectors. Because normal eyes likely exhibit some variation in the distribution of the RGC axons, this may play a role in normal eyes that do not comply with the ISNT rule.

The normal variability in the RNFLT may differ according to race, age, sex, refractive error, and axial length (11). Many researchers have examined the impact of ethnic factors on the RNFLT. Caucasians have a lower RNFLT compared to Hispanics, AfricanAmericans, and Asians $(12,13)$. In two studies performed using SD-OCT found that the mean RNFLT was $102 \mu \mathrm{m}$ in Japanese whereas that it was $97.2 \mu \mathrm{m}$ in German $(28,29)$. In a study that compared three OCT devices, the mean RNFLT was $11.5 \mu \mathrm{m}$ greater with the RTvue than with the Cirrus OCT and $4.5 \mu \mathrm{m}$ greater than with the Stratus OCT in the same population (23). Therefore, a normative database for each device and ethnicity is required to evaluate disorders properly.

We demonstrated that the mean RNFLT and fourquadrants RNFLT, with the exception of the inferior quadrant, decrease with age. Although some studies 
did not report a decrease in the RNFLT with age, most did show such a decrease $(13,15-17,30-34)$. These results are consistent with previous histological studies that reported a decrease in the density of photoreceptors and ganglion cells with age $(35,36)$. An age-related decrease in the RNFLT was observed, together with a reduction of 4000 axons/year, in a histological study (37). The reported rates of RNFLT change ranged from -1.5 to $-3.3 \mu \mathrm{m} /$ decade. The mean RNFLT changed at a rate of $-0.16 \mu \mathrm{m} /$ year and by quadrant the mean superior RNFLT showed the greatest tendency to decrease with age, whereas the change was minimal in the inferior quadrant (-0.23 and $-0.08 \mu \mathrm{m} /$ year, respectively) (38). Similarly reported that the mean RNFLT slope was $-0.24 \mu \mathrm{m} /$ year, while for the superior and inferior quadrants it was -0.43 and $-0.15 \mu \mathrm{m} /$ year, respectively (33). Alasil et al (13) showed that the greatest decline was in the superior quadrant $(0.21 \mu \mathrm{m} / \mathrm{year})$, followed by the mean RNFLT $(0.15 \mu \mathrm{m} /$ year $)$. We found a decrease in the mean RNFLT of $0.101 \mu \mathrm{m} /$ year. This is similar to but somewhat lower than reported in the literature. One possible explanation for this is related to the inclusion of only individuals with $20 / 20$ visual acuity. Although these findings support our result, contradictory data have been reported. In the literature also showed that the decrease in the superior and inferior quadrants was at a greater rate than in the temporal and nasal quadrants and the another study reported that the greatest absolute slopes were for the inferior and superior quadrants, and the clock hour $1(32,39)$. The cause of these differences is unknown, but it may be related at least in part to ethnic differences.

Although we found that the mean RNFLT was slightly greater in females, there was no significant difference between the sexes, with the exception of the superior quadrant. Kılıç et al (15) reported that the mean RNFLTs in males in females were 99.8 and $102.1 \mu \mathrm{m}$, respectively, but without any significant difference. They also reported that the temporal quadrant thickness was greater in females. Although these findings suggest that gender has a slight effect on the RNFLT, it appears to have no significant impact in the literature $(12,13,28,29,33)$.

\section{Relationships among the GCC, Age and Sex}

We demonstrated that the GCC thickness decreased in older subjects and that there was no difference according to gender. We found that the GCC thickness was less affected by age than the RNFLT. The decrease in the mean GCC thickness was $0.043 \mu \mathrm{m} /$ year. Kita et al (40) found no significant relationship between the GCC thickness and age, but reported a partial regression coefficient for the GCC of -0.15 for Hungarians and -0.11 for Japanese. These studies included a small simple size, 52 Hungarian and 50 Japanese. Similarly demonstrated that the GCC thickness did not change according to to age in young myopic subjects (41). In contrast, some research demonstrated that the GCC thickness decreased by $0.159 \mu \mathrm{m} /$ year, although they found no relationship with sex (42). Girkin et al (43) reported that the GCC thickness decreased by $0.1 \mu \mathrm{m} /$ year. We speculate that GCC change isn't uniform due to the GCC comprises three tissue layers. These tissues may have different response to aging process. Significant loss of retinal ganglion cells occurred in 12-week old mice although inner plexiform layer stratification remained unchanged at this stage (44). Other possible situation may be residual tissue. Complete loss of retinal ganglion cells in humans leaves a residual RNFL thickness due to residual blood vessels and glial cells (45).

\section{CONCLUSION}

The ganglion cell complex thickness and retinal nerve fiber layer thickness decreased significantly with age but ganglion cell complex thickness was less affected. Racial and ethnic changes may lead to differences which may result in delays in the diagnosis of disorders. Therefore, ethnicity should be taken into account to evaluate disorders properly.

This findings were presented on Turkish Ophthalmology National Congress in Antalya 2013.

Conflict of interest: Authors declare that there is no conflict of interest between the authors of the article.

Financial conflict of interest: Authors declare that they did not receive any financial support in this study.

Address correspondence to: Mehmet Adam, Aksaray University, Faculty of Medicine Department of Ophthalmology, Aksaray, Turkey

E-mail: drmehmetadam@gmail.com

\section{REFERENCES}

1. Quigley HA, Katz J, Derick RJ, et al. An evaluation of optic disc and nerve fiber layer examinations in monitoring progression of early glaucoma damage. Ophthalmology 1992;99:19-28.

2. Curcio CA, Allen KA. Topography of ganglion cells in human retina. J Comp Neurol 1990;300:5-25.

3. Tan O, Li G, Lu AT-H, et al. Mapping of macular substructures with optical coherence tomography for glaucoma diagnosis. Ophthalmology 2008;115:949-56. 
4. Seong M, Sung $\mathrm{KR}$, Choi $\mathrm{EH}$, et al. Macular and peripapillary retinal nerve fiber layer measurements by spectral domain optical coherence tomography in normal-tension glaucoma. Invest Ophthalmol Vis Sci 2010;51:1446-52.

5. Mwanza JC, Budenz DL, Godfrey DG, et al. Diagnostic performance of optical coherence tomography ganglion cell-inner plexiform layer thickness measurements in early glaucoma. Ophthalmology 2014;121(4):849-54.

6. Nakano N, Hangai M, Nakanishi H, et al. Macular ganglion cell layer imaging in preperimetric glaucoma with speckle noisereduced spectral domain optical coherence tomography. Ophthalmology 2011;118:2414-26.

7. Kim NR, Lee ES, Seong GJ, et al. Comparing the ganglion cell complex and retinal nerve fibre layer measurements by fourier domain oct to detect glaucoma in high myopia. $\mathrm{Br} J$ Ophthalmol 2011;95:1115-21.

8. Tan O, Chopra V, Lu AT-H, et al. Detection of macular ganglion cell loss in glaucoma by fourier-domain optical coherence tomography. Ophthalmology 2009;116:2305-14.

9. Yoon MH, Park SJ, Kim CY, et al. Glaucoma diagnostic value of the total macular thickness and ganglion cell-inner plexiform layer thickness according to optic disc area. $\mathrm{Br} J$ Ophthalmol 2014;98(3):315-21.

10. Anraku A, Enomoto N, Takeyama A, et al. Baseline thickness of macular ganglion cell complex predicts progression of visual field loss. Graefes Arch Clin Exp Ophthalmol 2014;252(1):109-15.

11. Poinoosawmy D, Fontana L, Wu JX, et al. Variation of nerve fibre layer thickness measurements with age and ethnicity by scanning laser polarimetry. Br J Ophthalmol 1997;81:350-4.

12. Budenz DL, Anderson DR, Varma R, et al. Determinants of normal retinal nerve fiber layer thickness measured by stratus oct. Ophthalmology 2007;114:1046-52.

13. Alasil T, Wang K, Keane PA, et al. Analysis of normal retinal nerve fiber layer thickness by age, sex, and race using spectral domain optical coherence tomography. J Glaucoma 2013;22:532-41.

14. Takeyama A, Kita $Y$, Kita $R$, et al. Influence of axial length on ganglion cell complex (gcc) thickness and on gcc thickness to retinal thickness ratios in young adults. Jpn J Ophthalmol 2014;58:86-93.

15. Kiliç A, Altintaş Ö, Yüksel $N$, et al. Optical coherence tomography measurement of retinal nerve fibre layer, optic nerve head and macula in normal subjects. NeuroOphthalmology 2010;34:36-44.

16. Celebi AR, Mirza GE. Age-related change in retinal nerve fiber layer thickness measured with spectral domain optical coherence tomography. Invest Ophthalmol Vis Sci 2013;54:8095-103.

17. Toprak AB, Yilmaz OF. Relation of optic disc topography and age to thickness of retinal nerve fibre layer as measured using scanning laser polarimetry, in normal subjects. $\mathrm{Br} \mathrm{J}$ Ophthalmol 2000;84:473-8.

18. Pehlivanoğlu S, Akar S, Gökyiğit B, et al. Sağlıklı çocuklarda optik kohorens tomografi ile retina sinir lifi tabakası kalınlığı ölçümü. Glokom-Katarakt 2010;5:218-22.

19. Kara N, Sayin N, Bayramoglu SE, et al. Peripapillary retina nerve fiber layer thickness and macular ganglion cell layer thickness in patients with obstructive sleep apnea syndrome. Eye (Lond) 2018;32(4):701-06.

20. Garas A, Vargha P, Hollo G. Reproducibility of retinal nerve fiber layer and macular thickness measurement with the rtvue-100 optical coherence tomograph. Ophthalmology 2010;117:738-46.

21. Leitgeb R, Hitzenberger C, Fercher A. Performance of fourier domain vs. time domain optical coherence tomography. Opt Express 2003;11:889-94.

22. Seibold LK, Mandava N, Kahook MY. Comparison of retinal nerve fiber layer thickness in normal eyes using time-domain and spectral-domain optical coherence tomography. Am J Ophthalmol 2010;150:807-14.

23. Lee ES, Kang SY, Choi EH, et al. Comparisons of nerve fiber layer thickness measurements between stratus, cirrus, and rtvue octs in healthy and glaucomatous eyes. Optom Vis Sci $2011 ; 88: 751-8$.

24. Garas A, Vargha P, Hollo G. Diagnostic accuracy of nerve fibre layer, macular thickness and optic disc measurements made with the RTVue-100 optical coherence tomograph to detect glaucoma. Eye 2011;25:57-65.

25. Harizman N, Oliveira $C$, Chiang $A$, et al. The isnt rule and differentiation of normal from glaucomatous eyes. Arch Ophthalmol 2006;124:1579-83.

26. Sihota R, Srinivasan G, Dada T, et al. Is the isnt rule violated in early primary open-angle glaucoma--a scanning laser tomography study. Eye 2008;22:819-24.

27. Cheung CY, Chen D, Wong TY, et al. Determinants of quantitative optic nerve measurements using spectral domain optical coherence tomography in a population-based sample of non-glaucomatous subjects. Invest Ophthalmol Vis Sci 2011;52:9629-35.

28. Hirasawa H, Tomidokoro A, Araie $M$, et al. Peripapillary retinal nerve fiber layer thickness determined by spectraldomain optical coherence tomography in ophthalmologically normal eyes. Arch Ophthalmol 2010;128:1420-26.

29. Bendschneider D, Tornow RP, Horn FK, et al. Retinal nerve fiber layer thickness in normals measured by spectral domain oct. J Glaucoma 2010;19:475-82.

30. Ramakrishnan R, Mittal S, Ambatkar S, et al. Retinal nerve fibre layer thickness measurements in normal Indian population by optical coherence tomography. Indian J Ophthalmol 2006;54:11-5.

31. Zhao $L$, Wang $Y$, Chen $C X$, et al. Retinal nerve fibre layer thickness measured by spectralis spectral-domain optical coherence tomography: The beijing eye study. Acta Ophthalmol 2014;92(1):35-41.

32. Lee JY, Hwang YH, Lee SM, et al. Age and retinal nerve fiber layer thickness measured by spectral domain optical coherence tomography. Korean J Ophthalmol 2012;26:1638.

33. Feuer WJ, Budenz DL, Anderson DR, et al. Topographic differences in the age-related changes in the retinal nerve fiber layer of normal eyes measured by stratus optical coherence tomography. J Glaucoma 2011;20:133-8.

34. Larsson E, Nuija E, Alm A. The optic nerve head assessed with hrt in 5-16-year-old normal children: Normal values, repeatability and interocular difference. Acta Ophthalmol 2011;89:755-8.

35. Gao H, Hollyfield JG. Aging of the human retina. Differential loss of neurons and retinal pigment epithelial cells. Invest Ophthalmol Vis Sci 1992;33:1-17.

36. Repka MX, Quigley HA. The effect of age on normal human optic nerve fiber number and diameter. Ophthalmology 1989;96:26-32.

37. Jonas JB, Schmidt AM, Muller-Bergh JA, et al. Human optic 
nerve fiber count and optic disc size. Invest Ophthalmol Vis Sci 1992;33:2012-8.

38. Parikh RS, Parikh SR, Sekhar GC, et al.Normal age-related decay of retinal nerve fiber layer thickness. Ophthalmology 2007;114:921-6.

39. Sung KR, Wollstein G, Bilonick RA, et al. Effects of age on optical coherence tomography measurements of healthy retinal nerve fiber layer, macula, and optic nerve head. Ophthalmology 2009;116:1119-24.

40. Kita Y, Naghizadeh F, Kita R, et al. Comparison of macular ganglion cell complex thickness to total retinal thickness ratio between Hungarian and Japanese eyes. Jpn J Ophthalmol 2013;57:540-5.

41. Zhao Z, Jiang C. Effect of myopia on ganglion cell complex and peripapillary retinal nerve fibre layer measurements: $A$ fourier-domain optical coherence tomography study of young chinese persons. Clin Experiment Ophthalmol 2013;41:5616.
42. Kim NR, Kim JH, Lee J, et al. Determinants of perimacular inner retinal layer thickness in normal eyes measured by fourier-domain optical coherence tomography. Invest Ophthalmol Vis Sci 2011;52:3413-8.

43. Girkin CA, McGwin G Jr, Sinai MJ, et al. Variation in optic nerve and macular structure with age and race with spectraldomain optical coherence tomography. Ophthalmology 2011;118:2403-8.

44. Albert-Fort M, Hombrebueno JR, Pons-Vazquez S, et al. Retinal neurodegenerative changes in the adult insulin receptor substrate-2 deficient mouse. Exp Eye Res 2014;124:1-10.

45. Hood DC, Fortune B, Arthur SN, et al. Blood vessel contributions to retinal nervefiber layer thickness profiles measured with optical coherence tomography. J Glaucoma 2008;17:519-28. 